\title{
ע Häpeä ja stigma mielisairaaloiden potilaiden ja heidän omaistensa muistoissa
}

\author{
Mielenterveysongelmiin liittyy korostunut häpeän tunne. Erityisesti mielisairaalaan joutuminen \\ on monelle häpeällinen kokemus, josta on vaikeaa puhua. Tässä artikkelissa tarkastelen \\ mielisairaalaan liittyvää häpeää psykiatristen sairaaloiden potilaiden ja heidän omaistensa \\ kirjoittamien muistojen valossa. Artikkeli pohjautuu Suomalaisen Kirjallisuuden Seura ry.n Muistoja \\ ja kokemuksia mielisairaaloista -muistoaineistoon, joka on kerätty 90 eri kirjoittajalta vuosina \\ 2014-15. Muistoista vanhin sijoittuu 1930-luvulle ja tuoreimmat 2010-uvulle. Pohdin, miten \\ häpeää kuvataan muistoissa, millaisiin tilanteisiin se liittyy ja miten se rakentuu keruukutsun \\ pohjalta muodostuneessa muistoaineistossa. Muistokeruumateriaalin erityisyys on otettu huomioon \\ aineiston analyysissa liittämällä tekstiin runsaasti aineisto-otteita, joiden kautta lukija saa \\ kokonaisnäkemyksen aineiston luonteesta sekä voi seurata analyysia ja sen johtopäätöksiä. \\ Potilaiden häpeän tunteissa korostuu stigma, joka on rakentunut osaksi omaa identiteettiä. \\ Häpeä kytkeytyy hoitojärjestelmän valtarakenteisiin ja käytettyihin pakkokeinoihin, kuten \\ eristykseen joutumiseen tai vastentahtoiseen psyykenlääkitykseen. Traumaattisia kokemuksia on \\ aineistossa usein kuvattu metaforisen kielen kautta. Koko aineistoa, mutta erityisesti potilaiden \\ omaisten muistoja, sävyttää ajatus häpeän ylisukupolvisuudesta ja taakkasiirtymistä. Vaikka asenteet \\ mielenterveysongelmia kohtaan ovat muuttuneet, on häpeä yhä toipumista hankaloittava seikka. \\ Sen vastavoimana voi kuitenkin nähdä toivon, jonka ylläpitämisessä ja herättämisessä potilaan \\ läheiset ja hoitotyöntekijät ovat keskeisessä roolissa.
}

\section{ASIASANAT: Mielisairaalat, häpeä, mielenterveysongelmat, psykiatrinen hoitotyö}

\section{KAROLIINA MAANMIELI}

\section{YDINASIAT}

- Mielenterveyden ongelmiin kytkeytyy yhä häpeää ja monet kokevat mahdottomaksi kertoa esimerkiksi hoitojaksoistaan psykiatrisessa sairaalassa.

- Häpeän kytkeytymistä psykiatriseen sairaalahoitoon ei ole aiemmin Suomessa tutkittu.

- Tulokset osoittavat, että korostuneet mielenterveysongelmiin liittyvät häpeän tunteet saavat usein alkunsa jo lapsuudessa ja mielisairaalassa koetut pakkotoimet ja muu nöyryyttävä kohtelu ovat syventäneet niitä. Sen sijaan läheisten ja hoitohenkilökunnan empaattinen ja ymmärtäväinen suhtautuminen ovat helpottaneet häpeän käsittelyä ja siitä toipumista.

- Hoidon laadun parantaminen ja potilaan mahdollisen traumataustan huomioiminen, pakkotoimien vähentäminen ja potilaan läheisten tukeminen olisivat toimivampia menetelmiä häpeän lievittämisessä kuin häpeän purkuun tähtäävät kampanjat, jotka hyvästä tarkoitusperästään huolimatta korostavat usein mielenterveyskuntoutujien toiseutta.

- Jatkossa tulisi tutkia potilaiden, heidän omaistensa ja hoitohenkilökunnan ajatuksia ja kokemuksia psykiatrisesta hoidosta. 


\section{JOHDANTO}

Psykiatriseen hoitoon liittyvä julkinen keskustelu keskittyy Suomessa usein osastohoidon riittämättömyyteen ja hoidon uudelleenjärjestelyyn sekä toisaalta vanhojen mielisairaalarakennusten ja -miljöiden suojeluun. Sairaalahoidossa olleiden ihmisten sekä heidän läheistensä muistot ja kokemukset ovat näissä pohdinnoissa jääneet sivurooliin. Potilaiden ja omaisten näkökulma puuttuu usein myös psykiatrian historiasta, sillä esimerkiksi sairaalahistoriikkien kirjoittajina ja haastateltavina on yleensä vain henkilökunnan edustajia. (2) Psykiatrian alalla valtanarratiivina voi pitää psykiatrien näkemystä hoidon jatkuvasta kehittymisestä, kun samalla mielenterveyden häiriöiden määrä jatkaa kasvamistaan ja potilaat kokevat usein hoidon riittämättömänä tai toisaalta kroonistavana häpeän ja stigman tuottajana. Tässä artikkelissa tarkastelen suomalaisten mielisairaalamuistoihin liittyvää häpeää, sen rakentumista ja siitä vapautumista Suomalaisen kirjallisuuden seuran vuosina 2014-15 keräämän Muistoja ja kokemuksia mielisairaalasta -aineiston (1) valossa. Tavoitteenani on antaa mielisairaalamuistojaan jakaneille potilaille ja heidän omaisilleen tilaisuus kertoa kokemuksiaan ja näkemyksiään mielenterveysongelmiin ja sairaalahoitoon liittyvästä häpeästä. Omaa tai perheenjäsenen psyykkistä sairastumista leimaavat usein syvä häpeä, salailu ja syyllisyydentunteet $(3,4)$. Häpeän käsite kattaa sopimattoman teon, huonommuuden tai muun vastaavan, aiheuttaman mielipahan, nolouden tai katumuksen tunteen tai arvonannon tai kunnian menetyksen (5).

Mielisairaalaan tai muuhun psykiatriseen hoitoon liittyviä häpeän tunteita ei ole Suomessa aiemmin tutkittu, vaikka mielenterveysongelmiin kytkeytyvästä häpeästä onkin tehty joitakin tutkimuksia. Korkeilan ym. (6) toimittama artikkelikokoelma Irti häpeäleimasta tarkastelee häpeää monipuolisesti niin hoitohenkilökunnan, omaisten kuin mielenterveyden ongelmista kärsivien henkilöidenkin näkökulmasta. Korkeila tarkastelee häpeän teemoja kummien kokemusten ja psykoosin viitekehyksistä myös tuoreessa artikkelissaan (7).

Kulmalan (8) väitöstutkimuksessa pohditaan mielenterveyskuntoutujien kokemuksia leimatusta identiteetistä ja toiseudesta. Hänen aineistonaan käytettämän kirjoituskutsun vastaukset ja haastattelut ovat syntyneet tilanteissa, joissa ihmiset joutuvat usein vahvojen ongelmalähtöisten määrittelyjen kohteiksi. Kulmalan aineistossa tuli näkyviin, että ihminen rakentaa käsitystä itsestään ulkopuolisten määritelmien kuten psyykkisten diagnoosien mukaan. Ne tuovat tullessaan kokemuksia leimatusta identiteetistä. Jähin (9) tutkimus lasten kokemuksista vanhemman psyykkisestä sairastumisesta osoittaa, että mielenterveysongelmien ja niihin liittyvän häpeän perinne voi ulottua myös seuraavaan sukupolveen. Hyvärin (10) artikkeli pohtii syrjäytymisen ja stigman vastaista kamppailua kahden potilastarinan kautta. Myös kulttuurintutkimuksen alalla lähivuosina julkaistut psyykkisen sairauden kulttuurista rakentumista pohtivat tutkimukset $(11,12,13)$ sivuavat häpeää ja stigmaa. Sekä suomalainen että kansainvälinen häpeän tutkimus nojaavat yhä Erving Goffmanin 1960luvulla luomaan stigmateoriaan (14). Stigmalla eli häpeäleimalla tarkoitetaan sosiaalista leimaamista, jossa yksilön arvoa ja ihmisyyttä arvioidaan jonkin muista poikkeavan, ei-toivotun ominaisuuden kautta.

Tutkimukseni viitekehys on kulttuurisessa mielenterveystutkimuksessa (15). Sen tiimoilta tänä keväänä ilmestynyt artikkelikokoelma $\mathrm{Hul}$ luus ja kulttuurinen mielenterveystutkimus liittyy hulluustutkimuksen (12) perinteeseen, mutta ottaa lähtökohdakseen hulluuden määrittelyn terveyteen liittyvänä kysymyksenä. Näin sen juuret ovat myös kulttuurisessa terveystutkimuksessa (16). Kulttuurisen mielenterveystutkimuksen viitekehyksessä hulluus käsitetään kulttuurisena ilmiönä, johon liittyy vahvoja tunteita, uskomuksia ja tulkintoja. Monet niistä liittyvät juuri häpeän kokemuksiin. Hulluuden käsite kokoaa yhteen toiminnan ja olemisen muotoja, jotka eri historiallisissa, sosiaalisissa ja kulttuurisissa konteksteissa on koettu tai koetaan epätavalliseksi tai omituiseksi. Se voidaan ymmärtää sosiaaliseen konstruktionismiin pohjautuvaksi käsitteeksi ja ilmiöksi, joka vain osittain kytkeytyy psykiatriaan. $(12,15$.

\section{TUTKIMUSAINEISTO JA -MENETELMÄT}

Artikkelini on osa monitieteistä, Muistoihin kaivertuneet tilat (2017-2020) hanketta, jossa työskentelee viisi tutkijaa. Hanke keskittyy Muistoja ja kokemuksia mielisairaaloista -keruuaineiston (1) analyysiin. Aineisto koostuu 91 tekstistä, jotka ovat potilaiden, hoitohenkilökunnan, potilai- 
den omaisten ja läheisten sekä henkilökunnan lasten kirjoittamia. Mielisairaalamuistokeruun ohjeistuksessa kirjoittajia pyydettiin kuvaamaan esimerkiksi hoitokokemuksia, kohtaamisia sairaalassa, sairaala-ajan merkitystä elämässä sekä sairaalarakennusta ympäristöineen. Ohjeistus oli laadittu väljäksi, koska kirjoittajien haluttiin valitsevan oman lähestymistapansa aiheeseen. Valitsin aineistosta otokseeni mielisairaaloita potilaan roolista käsin tarkastelevat 45 muistoa sekä kaksi omaisen muistoa, jotka käsittelivät häpeän kysymyksiä. Liitin otokseeni tutkimusryhmällemme keräyksen päättymisen jälkeen lähetetyn potilaan/omaisen muiston. Muistot sijoittuvat 24 eri sairaalaan. Kaikkien vastaajien sairaalajakson ajankohta ei ole tiedossa, mutta aineistossa painottuvat 1980-2000-luvuille ajoittuvat muistot. Aineiston vanhimman, 1930-luvulta peräisin olevan tekstin on lähettänyt keräykseen kirjoittajan sukulainen. Tuoreimmat muistot on kirjoitettu psykiatrisesta sairaalasta käsin vuonna 2015. Kirjoitusten pituus vaihtelee lyhyestä runosta yli sataan konekirjoitusliuskaan. Yhteensä aineisto muodosti 500-sivuisen kokonaisuuden.

Tutkimusmenetelmänäni käytän lähilukua, joka Pöysän (17) mukaan soveltuu kirjoituskutsun kautta kerätyn muistoaineiston analyysiin. Olen palannut aineiston teksteihin useita kertoja, jolloin lukutapani on muuttunut ja aineistosta paljastunut uusia seikkoja. Olen myös tehnyt merkintöjä muistotekstin oheen ja reflektoinut muistoja kirjoittamalla. Tutkimusmetodissani on piirteitä narratiivisesta analyysista, sillä muistot ovat muodoltaan kertomuksellisia ja pyrkivät tulkitsemaan ja valikoimaan menneisyyden tapahtumia (17). Hain aineistosta kirjoituksia, joissa kuvataan häpeää ja sille läheisiä teemoja (arvottomuuden tai avuttomuuden tunnetta, traumakokemuksia, nolouden, alistamisen ja nöyryytyksen kokemuksia) jotka liittyivät joko omaan tai läheisen ihmisen sairastumiseen tai sairaalaan joutumiseen. Häpeää kuvataan muistoissa paitsi suorasanaisesti, myös metaforien kautta (18). Tutkijoiden mukaan häpeän juuret ovat löydettävissä jo vauvaiän kokemuksista, kun vauva ei kohtaa äidin kasvoissa etsimäänsä hyväksyvää katsetta. Häpeää voidaan siis pitää reaktiona hyväksyvän vastavuoroisuuden puutteeseen (19).

Mielisairaalamuistoja tarkastellessani hyödynnän sisäistetyn häpeän (20) käsitettä. Tätä on käytetty varsinkin psykoterapiaan liittyvässä häpeän tutkimuksessa (21). Sisäistetty häpeä ei tapahtumasidonnaisen häpeän tavoin kytkeydy ainoastaan yksittäiseen tapahtumaan tai tekoon, vaan on tullut osaksi minäkuvaa ja synnyttänyt kokemuksen syvästä arvottomuudesta. Se liittyy varhaisiin hylkäämisen, nöyryyttämisen ja arvostelun kokemuksiin ja on yhteydessä myöhemmän elämän psyykkisiin vaikeuksiin. $(20,21$.) Esimerkiksi asumispalveluissa asuvien nuorten perheenjäsenet saattavat hävetä nuoren sairautta ja kieltää jopa puhumasta siitä (22). Tämänkaltaiset läheisten suhtautumistavat ovat osaltaan rakentamassa sisäistettyä häpeää.

Teemoittelin otokseeni valikoimiani tekstejä sen mukaan kuvattiinko niissä häpeän tunteita, mihin häpeän tunteet kohdistuivat ja miten niistä kirjoitettiin. Kiinnitin erityistä huomiota niihin muistoihin, jossa kuvattiin mielen sairauksien ja mielisairaalaan joutumisen yleistä hävettävyyttä ja salailua tai muisteltiin kirjoittajan lapsuuteen ajoittuvia häpeän kokemuksia. Monet kirjoittajat kertoivat ajatuksen psyykkisten sairauksien ja mielisairaalaan joutumisen tabuluonteesta alkaneen syntyä jo lapsena. Henkilökohtainen kerrottu kokemus on kietoutunut kulttuuriseen merkityksenantoon - erityisesti silloin kun puhutaan vahvoja tunteita herättävistä aiheista. Tutkin, miten lapsuuden aikaisia häpeäkäsityksiä kuvataan ja heijastuvatko lapsuusiän kokemukset nykyhetken häpeän tunteisiin ja asenteisiin. Analyysissa kiinnitän huomiota siihen, miten lapsuutta muistellaan ja kommentoidaan nykypäivästä käsin. Näissä muistoteksteissä konkretisoituu myös häpeän ylisukupolvisuus.

Toisena erityishuomioni kohteena olivat tekstit, jossa kuvattiin psykiatrisen hoidon roolia häpeän aiheuttajana tai lievittäjänä. Kulttuurisessa mielenterveystutkimuksessa psykiatria, mielisairaudet ja mielisairaalat nähdään eri asemissa olevien henkilöiden välisten kohtaamisten sekä käsitysten, ideologioiden ja käytänteiden risteyskohtana (15). Analysoin näitä usein kipeitä tunteita sisältäviä kohtaamisia nostamalla aineistosta runsaasti tekstiesimerkkejä ja tarkastelemalla häpeää herättäneiden konfliktitilanteiden kuvailussa käytettäviä metaforisia ilmauksia. Varsinkin niissä tapauksissa, jossa sairaalahoitoon joudutaan vastentahtoisesti tai hoidon aikana käytetään pakkokeinoja, potilaat kokevat häpeää omien fyysisten rajojen ylittämiseen liittyen. 
Analyysini lopuksi tarkastelin miten, missä määrin ja minkälaisten asioiden tukemana vastaajat ovat mahdollisesti pystyneet käsittelemään häpeän kokemuksiaan ja toipuneet niistä.

\section{EETTINEN POHDINTA}

Mielisairaalamuistot ovat arkaluontoisia ja henkilökohtaisia, joten niiden analysoiminen edellyttää tutkimuseettistä pohdintaa (23). Mielisairaalapotilaita koskevaan muistokerrontaan liittyy erilaisuuden ja normaaliuden välistä rajantekoa ja mahdollista toiseuden tuottamista (11). Jäntti ym. (15) painottavat kulttuurisen mielenterveystutkimuksen mahdollisuuksia nostaa esiin käytänteitä ja totuttuja ajattelutapoja, joiden kautta mielenterveysongelmiin liittyvää stigmaa tuotetaan ja uusinnetaan.

Sensitiivisten aiheiden tutkimuksessa myös käsitevalinnat vaativat eettistä pohdintaa. Tässä artikkelissa olen päätynyt käyttämään yleiskäsitettä mielisairaala myös uudempiin muistoihin viitaten. Tämän valinnan olen tehnyt sekä yhtenäisyyden vuoksi että keruukutsun ja aineiston linjaamana. Muistelijat itse käyttivät lähes poikkeuksetta mielisairaala-termiä. Myös hulluus on terminä ristiriitainen ja mahdollisesti loukkaava. Sen käyttöön päädyin toisaalta tutkimuksen viitekehyksen vuoksi, toisaalta siksi, että myös muistoaineistossa monet kirjoittajat ovat käyttäneet samaa käsitettä. Tätä mielenterveyskuntoutujien itsensä tekemää termivalintaa voidaan pitää voimauttavana, kapinallisen ryhmäidentiteetin merkkinä (15).

Konstruktiivisen, henkilökohtaisen ja valikoituneen muistitiedon tulkitseminen edellyttää tutkijalta sensitiivisyyttä ja omien emansipatoristen motiivien tunnistamista (24). Itseäni tutkijana ja kirjallisuusterapiaohjaajana motivoi potilaiden kokemustiedon saattaminen näkyväksi. Olen tehnyt oman työurani mielenterveyskuntoutujien avohoidossa, jossa esimerkiksi pakkokeinojen käyttö ei ole ollut mahdollista kuin psykiatrin - usein potilaan hoitotahdon vastaisesti - määräämän psyykelääkityksen muodossa. Tämä värittää analyysiani ja erityisesti lääkitykseen liittyvien muistojen luentaani. Olen pyrkinyt lisäämään analyysini luotettavuutta reflektoimalla tulkintojani yhdessä tutkijaryhmämme kanssa säännöllisissä tapaamisissa.

Anonymiteetin turvaamiseksi teksteistä on poistettu kirjoittajien nimet. Joissain tapauksissa tämä ei välttämättä ole ollut oikea ratkaisu, sillä osa kirjoittajista ehkä haluaisi esiintyä omalla nimellään. Katsoin kuitenkin parhaaksi pitäytyä otteiden nimettömyydessä, koska tekstit liittyvät muidenkin kuin kirjoittajiensa elämään - niistä olisi kirjoittajan nimen perusteella helppo tunnistaa myös muita ihmisiä.

\section{TULOKSET}

\section{I. LAPSUUDEN AIKAISET HÄPEÄN KOKEMUKSET}

Monet aineiston muistoista sijoittuvat kokonaan osittain kirjoittajan lapsuuteen - joko niin, että hän on joutunut hoitoon jo lapsena tai on lapsuudessaan seurannut vanhempansa, sisaruksensa tai jonkun muun sukulaisensa sairaalaan joutumista tai katsoo oman myöhemmän sairastumisensa kiinteästi liittyvän lapsuuden tapahtumiin. Monet kirjoittajat kertovat lapsena oppineensa, että psyykkisessä sairastumisessa ja mielisairaalaan joutumisessa on jotain hävettävää. Tämä käsitys voi syntyä esimerkiksi muiden lasten kommenttien ja pilkkaamisen kautta, kuten tässä potilaan lapsen muistossa:

\begin{abstract}
"Varhaisin muisto mielisairaalasta liittyy kesäiseen päivään, kun me ala-asteen ensimmäisillä luokilla olevat naapurukset seisomme pienen maalaiskunnan pihatiellä ja kiistelemme jostain. Äkkiä yksi vanhemmista pojista hermostuu ja tokaisee: 'Törnävälle'. Toiset innostuvat ja hokevat alakynteen jääneelle tytölle Törnävälle, Törnävälle" Silloin en tiennyt, että Törnävä on sadan kilometrin päässä oleva mielisairaala. Myöhemmin kävin siellä isääni katsomassa.” (1, SKS 370)
\end{abstract}

Äärimmillään häpeä perheenjäsenen sairastumisesta voi johtaa siihen, että tämän sairaalaan joutuminen pyritään salaamaan ja siitä kielletään puhumasta muille. Näin salailu muodostuu tärkeämmäksi kuin yhteydenpito omaiseen:

”Kun olin kymmenvuotias (...) isäni olikin suljetulla osastolla, Törnävällä. Päätimme ilahduttaa isää kortilla. Valitsimme sen tarkkaan, ja osoitekenttäkin oli jo täytetty, kun äitini totesi, ettei sitä voi lähettää, muutoinhan kylillä saataisiin selville missä isä on.” (1, SKS 370) 
Muistoaineistossa on muutamia tekstejä, joiden kirjoittaja muistelee mielisairaaloita sekä omaisen että potilaan roolissa. Rankimmillaan koko kahdeksanhenkinen ydinperhe on käynyt läpi hoitojaksoja psykiatrisessa sairaalassa (1, SKS 002). Lasten kokemuksia läheisen psyykkisestä sairastumisesta voi tutkia ajallisesti kahdesta suunnasta - toisaalta sitä, millaisia kokemuksia lapsen kannalta liittyy vanhemman psyykkiseen sairastumiseen ja millaisia merkityksiä tälle sairastumiselle myöhemmin annetaan osana elämää. Kun suvussa on paljon mielenterveyden ongelmia, voi oman mielen järkkymisen ja sairaalaan joutumisen uhka olla läsnä ja siihen liittyvä kohtalonomaisuus voi jälkikäteen ohjata niin läheisten ihmisten kuin ammattilaistenkin odotuksia ja tulkintoja. (13) Joissain aineiston muistoissa kuvataan, miten lapsuuden tai nuoruuden aikainen häpeä perheessä puhjenneesta sairaudesta, seksuaalisesta hyväksikäytöstä tai väkivallasta sävyttää koko elämänkulkua. Poimin muistoteksteistä analysoitaviksi ne kohdat, joissa vastaajat vertailivat tavalla tai toisella lapsuutensa aikaisia häpeäkokemuksia kirjoittamishetken ajankohtaan. (25). Vertailun kautta vastaajat pyrkivät esimerkiksi tekemään menneisyyttään lukijalle ymmärrettäväksi, ja luomaan elämäntarinalleen loogisen jatkumon, kuten tässä jatkosodan ajan muistoja kuvaavassa muistossa:

"Veljeni sairaus vaikutti koulunkäyntiini. Perhettämme alettiin kutsua hullujen porukaksi. (...) Äiti oli ainoa, joka piti yhteyttä veljeemme. Me muut pelkäsimme leimautumista, enkä koskaan sanonut, että veljeni on mielisairaalassa. (...) Ennen naimisiin menoa kerroin miehelleni veljeni sairaudesta. Suvun saatua tietää asiasta sain tyhmän ja hulluuteen taipuvaisen leiman, köyhän piikatytön leiman lisäksi.” (1, SKS 427)

Muiston kirjoittajan veli joutui monien muiden potilaiden tavoin sairaalahoitoon rintamalla kokemiensa traumojen jälkiseurauksena. Teksti kuvaa osuvasti sitä kokonaisvaltaista häpeää, joka saattaa leimata sairastuneen itsensä lisäksi myös hänen perheenjäsenensä. Samassa muistossa näkyy myös luokkayhteiskunnan vaikutus häpeän syventäjänä. Sodan psyykkisesti järkyttämiä miehiä pidettiin epänormaaleina ja muita miehiä heikompina, eikä monillekaan tullut mieleen kysyä, voisiko mielen järkkyminen olla luonnollinen ja tavallaan terve seuraus sodan kauhujen ja järjettömyyden kohtaamiseen (26). Kotiutuneiden miesten mielenterveysongelmia hävettiin ja salailtiin. Olikin tavallista, että kipeä sotakokemus jäi käsittelemättömäksi ja puhumattomaksi traumaksi, joillekin jopa koko loppuelämän ajaksi. (26.)

\subsection{HÄPEÄN YLISUKUPOLVISUUS JA TAAKKASIIRTYMÄ}

Usean nykyajankin sairaalapotilaan perhehistoriasta löytyy rankkoja, usein puhumattomia ja koteloituneita sotatraumoja. Tällaisia kutsutaan taakkasiirtymiksi tai ylisukupolvisiksi traumoiksi. Taakkasiirtymä-käsitteen on luonut Martti Siirala 1960-luvulla. Hänen mukaansa se, mikä ei tule yhdessä jaetuksi, tulee jonkun kannettavaksi eli taakkasiirtymäksi. Pirkko Siltalan mukaan taakkasiirtymäksi sanotaan puhumattomien ja käsittelemättömien traumaattisten kokemusten perintöä sukupolvesta seuraavalle. Nykyään samasta ilmiöstä käytetään termiä ylisukupolvinen trauma. Ilmiöön sisältyy ajan moniulotteisuus: meitä ympäröi nykyisyys, menneisyys ja tulevaisuus. Se merkitsee myös mahdollisuutta muutokseen ja taakkasiirtymän perinnön katkaisemiseen. Yhteinen kokemukseen pohjautuva tieto johtaa ylisukupolvisten traumojen jakamiseen ja antaa toivon näkökulman. (27.) Myös veljensä mielisairaalaan joutumista edellä muistellut kirjoittaja kertoo myöhemmin päässeensä yli perheenjäsenen sairastumiseen liittyvästä häpeästä ja haluavansa nyt puhua asiasta avoimesti.

Sukupolvinäkökulma näkyy aineistossa paitsi potilaiden, myös heidän omaistensa kirjoittamissa sairaalamuistoissa. Sisaruksen psyykkinen sairastuminen voi järkyttää lasta tai nuorta syvästi. Perheenjäsenen sairastumisen aiheuttamaan häpeään kytkeytyy myös pelkoa, joka voi liittyä pohjimmiltaan lamauttavaan ajatukseen mahdollisesta omasta sairastumisesta. Tämän 1980-luvulle ajoittuvaa siskonsa mielisairaalaan joutumista kuvaava muistelija kiteyttää näin:

"Pelottavinta Ellin (nimi muutettu) sairastuneessa hahmossa olivat silmät. Silmät katsoivat minua kohti, näkemättä tuntematta huomaamatta minua, silmät tuijottivat silmieni sisään mutta kuitenkin ohi, lävitseni, äärettömyyteen, pahuuteen. Omaan hulluuteeni. Pelotti sekin, että tulenko jonain päivänä 
hulluksi itsekin. Se pelko eli pitkään, vaappui jossain varjojeni takana, kunnes poistui sairastumiseni myötä. Minun ei enää tarvinnut pelätä tulevani hulluksi. Minä olin jo.” (28)

Omaisten, varsinkin omien vanhempien ja puolison, kokema häpeä ja salailu voi tuntua sairastuneesta itsestään hyvin kipeältä. Mielisairaalajaksot jäävät liian usein suvun puhumattomiksi salaisuuksiksi, kuten tässä 1990-luvulle sijoittuvassa muistossa:

"Suvussani oli mielenterveysongelmia. Myös veljeni ja tätini olivat olleet Moisiossa potilaina. Minun sairastuminen ja joutuminen mielisairaalaan on jäänyt jokseenkin julkiseksi salaisuudeksi. Niistä ajoista ei paljon enää puhuta. Minulle on jäänyt ikäväksi muistoksi se, etteivät vanhemmat käyneet minua sairaalassa katsomassa." (1, SKS 241)

\subsection{PSYKIATRINEN HOITOJÄRJESTELMÄ HÄPEÄN AIHEUTTAJANA JA SYVENTÄJÄNÄ}

Varsinkin vastentahtoiseen sairaalahoitoon joutumiseen sekä pakkokeinojen käyttöön liittyy häpeällinen kokemus omien fyysisten rajojen ylittämisestä, kelpaamattomuudesta ja toiseudesta. Tämä syventää mielenterveysongelmien stigmaa. Monissa potilaiden muistoissa korostuu hoitajien ja potilaiden eriarvoisuus, kohtaamisen ja kuuntelun puute sekä potilaiden tunteiden sivuuttaminen. 1990-luvulle sijoittuva potilaan muisto kuvaa, kuinka uusi potilas menee koputtamaan hoitajien kanslian ovelle hoitaakseen käytännön asioitaan ja saa heti huomata, että normaalit kanssakäymisen säännöt ja kohteliaisuus eivät sairaaloissa pädekään. Kirjoittaja kuvaa hoitajan taholta kokemaansa välinpitämättömyyttä ja sen haavoittavuutta kärpäsmetaforan avulla "Hoitaja huiskaisi kädellään minut pois kuin kärpäsen poskeltaan" (1, SKS 151) ja kertoo menneensä loukkaantuneena ja nöyryytettynä huoneeseensa itkemään.

Kielteiset muistot keskittyvät aineistossa tiettyihin sairaaloihin ja ovat yhteydessä niissä vielä 1990-luvullakin toteutettuun hyvin autoritaariseen hoitokulttuuriin. Seuraava entisen potilaan, myöhemmin sairaanhoitajan toimineen muistelijan kirjoitelma kuvaa, miten potilaisiin empaattisesti suhtautuvaa, läsnä olevaa ja kuuntelevaa hoitajaa saatetaan jopa kiusata työyhteisössä: ”...päätin, että keskityn vain omaan työhöni ja suren sitten, jos minusta tulee samanlainen tympääntynyt hoitaja kuin enimmät. Toisaalta myös työyhteisön paine laiskuuteen ja koneella olemiseen vaikutti, sillä jos teki työnsä liian potilaslähtöisesti, joutui syrjityksi ja työpaikkakiusatuksi.” (1, SKS 383)

Erityisen ongelmallista mielenterveyden ongelmien stigmatisoinnissa on se, että usein hoitohenkilökunnan asenteet ovat muuta väestöä ennakkoluuloisempia (29). Tutkimuksen mukaan varsinkin biologisiin selitysmalleihin uskovilla hoitohenkilöstön jäsenillä on taipumus kokea potilas epänormaalina, varsin erilaisena kuin muut ihmiset. Tämän seurauksena hoitosuhteeseen liittyy etäännyttämistä, eristämistä ja epäihmismäistä suhtautumista. Sosiaalisen stigman kuvaus toistuu muistoissa riippumatta siitä, mihin ajanjaksoon sairaalakokemus sijoittuu. Aineiston tuorein ja vanhin muisto käsittelivät molemmat hulluuteen liittyvää häpeäleimaa. Molempiin liittyy myös näkemys hulluuden pysyvyydestä ja sairaaloiden kyvyttömyydestä parantaa potilaitaan. Tuoreessa, vuoteen 2015 sijoittuvassa mielisairaalamuistossa kuvataan toistuvia sairaalajaksoja, joiden myötä oman hulluuden on jo alkanut omaksua osaksi identiteettiä:

"Hulluus stigmatisoi. Ensimmäisellä kerralla sen huomasi selkeimmin. Tunsin, kuinka kaikki tiesivät, vaikkei todellisuudessa kukaan. Nyt alkaa olla jo omaksunut olevansa hullu.” (1, SKS 454)

1930-luvun muistossa taas korostuu näkemys sairaalasta tarpeettomien ihmisten huonona säilytyspaikkana, jonne potilas itse ei koe kuuluvansa:

"Eivät mielisairaalat mitään sairaaloita olekaan, eivät missään merkityksessä. $\mathrm{Ne}$ ovat ainoastaan yhteiskunnallisen roskan huonoja kaatopaikkoja.” (1, SKS 019)

Häpeän tunteet voivat olla taustalla silloin, kun oma itse kuvataan huonoksi, riittämättömäksi tai alistetuksi - esimerkiksi lukkojen takana tai häkissä olemiseen ja kiinni jäämiseen viittaavat metaforat kertovat häpeän tuntuvan intensiiviseltä ja sitovalta: siitä on vaikea irrottautua $(30,31)$. Kipeät kokemukset on muistoteksteissä ilmaistu 
usein metaforisesti vertaamalla sairaalaa vankilaan, armeijaan tai johonkin muuhun totalitaariseen laitokseen. Epäinhimillistä kohtelua on puolestaan kuvattu eläinmetaforin (18). Usein häpeä liittyy erityisen vahvasti diagnoosin saamiseen. Diagnosointi ja siihen liittyvät käytännöt sekä kliininen kielenkäyttö yleensä näyttävät pahentavan stigmaa (32). Anttonen (33) pohtii artikkelissaan, miten psyykkisen diagnoosin saanut helposti alkaa leimata itse itseään ja omaksuu sairastuneen identiteetin. Tämä estää näkemästä omia vahvuuksia ja niitä piirteitä, jotka eivät välttämättä sovi diagnoosin kuvaukseen.

Eräs kirjoittajista, jonka sairaalajaksot ovat sijoittuneet 1980-luvun loppuun ja 2010-luvulle kuvaa koko elämäänsä sävyttämää kokonaisvaltaista häpeää. Hän kokee, ettei vakavista mielenterveysongelmista ole mahdollista avoimesti puhua kenellekään, koska niihin liittyy niin vahva stigma. Tämä kapeuttaa sosiaalista elämää:

"Joillekin olen saattanut paljastaa, että joskus olen ollut hieman hoidossa ja syönyt psyykelääkkeitä, 'kun on ollut kriisi päällä', mutta tuollaiseen ympäripyöreään mitään kertomattomaan ilmaisuun se on jäänyt. Eihän sitä - Herra Jumala! - voi kahvipöydässä ilmoittaa olevansa skitsofreenikko. Ei kukaan sen jälkeen ottaisi sinua vakavasti. (1, SKS 251)

Psykiatriset hoitokeinot itsessään, varsinkin vahva psyykenlääkitys, voivat aiheuttaa välillisesti häpeän tunteita lisääviä muutoksia. Monet lääkityksen haittavaikutuksista, kuten pidätyskyvyttömyys, lisääntynyt syljeneritys, ylipainon kertyminen sekä varsinkin aiemmin käytössä olleisiin lääkkeisiin liittyneet silmien veto-oireet, jähmeys ja ilmeettömyys (34) vaikuttavat mielenterveyskuntoutujan olemukseen ennakkoluuloja vahvistavasti. Ylilääkitty potilas ei välttämättä myöskään jaksa huolehtia hygieniastaan, mikä lisää sosiaalista häpeää.

"Psyykenlääkkeet ja niiden sivuvaikutukset aiheuttivat voimakkaita kehon ja aistien muutoksia. Oli pelottavaa huomata, kuinka oma keho muuntui jähmeäksi ja hitaaksi ja puhe kuin humalaisen sammallukseksi. Rankinta oli vaihe, jolloin - joko sopimattoman tai liian suuren lääkityksen takia - käteni käpristyivät toimintakyvyttömiksi ja leukani vääntyi melkein sijoiltaan. Oli pelottavaa tulla vieraaksi itselleen, varsinkin kun ymmärsin sen johtuvan lääkkeistä, joita tuntemattomat ihmiset pakottivat ottamaan joko tabletteina tai injektioina, joita kammosin.” (28)

Lääkitys voi myös vähentää stigman syntymistä silloin, kun se ehkäisee sosiaalisesti paheksuttua käyttäytymistä ja eriskummallisia oireita. Näissäkin tilanteissa lääkehoidon toteutus lääkkeitä "määräämällä" ilman potilaan kuulemista ja hänen näkökulmansa huomioonottoa voi johtaa siihen, että lääke muodostuu symboliksi kuuntelemattomuudesta ja kohtaamattomuudesta sekä sairauteen liittyvästä häpeästä. (35) Tämä heikentää olennaisesti psyykkistä hyvinvointia ja voi johtaa muun muassa omaehtoiseen lääkehoidon keskeyttämiseen ilman suunniteltua vähennystä ja hoidollista tukea. Potilas voi myös kokea autoritaariset lääkkeenottotilanteet nöyryyttävinä:

\begin{abstract}
"Peloistani huolimatta päädyin muiden lailla seisomaan lääkejonossa, odottamassa omaa vuoroani kallistaa pienen muovikipon sisältö kämmenelleni ja nielaista pelkäämäni pillerit. Myönnän kyllä, että tarvitsin lääkitystä (vai tarvitsinko?) toipuakseni, mutta tuo liukuhihnamaisessa jonossa seisominen oli kyllä nöyryyttävää.” (28)
\end{abstract}

\subsection{HÄPEÄSTÄ TOIPUMINEN}

Siinä missä läheisten ihmisten hylkääminen ja sairastumisen tai sairaalaan joutumisen salailu ja niistä puhumisen välttely syvensivät häpeän tunteita, kuvattiin monissa muistoissa perheenjäsenien ja ystävien hyväksyvän suhtautumistavan suojaavan häpeältä ja ehkäisevän itsesyytöksiä. Tällöin sairaalan nöyryyttävät hoitokäytännöt ja sairauden tai lääkityksen aiheuttamat oireet koettiin tapahtumasidonnaisena häpeänä eivätkä ne vaikuttaneet syvästi omaan identiteettiin. Läheisten tuen voimin moni oli selviytynyt vaikeuksistaan ja alkanut pitää sairaala-aikaa tai psykoottista episodia tärkeänä ja opettavaisena kokemuksena. Psykoottisessa tilassa ihminen ei useinkaan kunnioita sosiaalisia konventioita, ja voi toivuttuaan kokea psykoosin aikana tekemistään asioista voimakastakin häpeää, jonka käsittelyssä omaisten ymmärtävä suhtautuminen auttaa.

Sairaalahoito esitellään aineistossa häpeää tuottavana asiana. Muistojen joukossa on kuiten- 
kin muutamia poikkeuksia, jossa nimenomaan korostetaan sen lievittäneen häpeää. Yksi kirjoittajista kertoo pystyneensä sairaalajaksonsa aikana 2000-luvulla vihdoin paljastamaan kipeän perhesalaisuuden ja saaneensa realistisemman käsityksen mielenterveysongelmien luonteesta. Etukäteisaikomuksestaan huolimatta kirjoittaja on myös jälkikäteen kertonut muille ihmisille avoimesti sairaalassa olostaan:

"Matkalla jo tiesin, että olen menossa 'maailmaan' jossa kehtaan kertoa lapsuudestani... Olin hoidossa kuusi viikkoa. Tämän jakson aikana kerroin siskoilleni ja vanhemmilleni hyväksikäytöstä. Sisarukset olivat kokeneet saman. Samoin äiti. Kaikki (...) lukivat kirjoittamansa kirjeen hyväksikäyttäjälle. Vihdoin näin sisaruksissani surua, katkeruutta, vihaa. Saimme murrettua salaisuuden osastojakson aikana.” (1, SKS 357)

Monissa muistoissa kuvataan, kuinka hyvä hoitosuhde on helpottanut häpeän käsittelyssä. Usein jo yksi empaattinen ja kuunteleva hoitotahon edustaja on mahdollistanut toipumisen käynnistymisen ja kipeiden tunteiden prosessoinnin. Monille muistoille on leimallista eri sairaaloissa vietettyjen jaksojen kokeminen eri tavoin, äärimmillään yhtä sairaalaa kuvattiin helvettinä ja toista taivaana, kuten tässä 1970-luvulle sijoittuvassa muistossa, jossa ensimmäinen vastentahtoinen sairaalahoito kuvattiin hyvin traumaattisena, mutta seuraava vapaaehtoinen sairaalajakso sai aikaan positiivisia muutoksia elämässä:

”Hassua kyllä, sairaala näyttäytyi tällä kertaa täydellisenä auvon tyyssijana. Hoitajat olivat kivoja ja asiallisia, lääkärit suorastaan nerokkaita, ja kuntouttavaa toimintaa oli sairaalasta alkaen aina kotiinpääsyn ylikin. Olin kai kolme kuukautta siellä jos oikein muistan. Mieleni ja muistini on täynnä kiitollisuutta ja helpotusta.” (1, SKS 385)

Jotkut muistelijat kertovat häpeästä toipumisessa keskeistä olleen oman suhtautumistavan muuttaminen, avun vastaanottaminen ja oman sairastumisen, herkkyyden tai erityislaadun hyväksyminen. Menneisyyden käsittelystä ja hyväksymisestä kielii myös muistokeruuseen osallistuminen, jolle monet kirjoittajat antoivat yhteiskunnallisen vai- kuttamisen merkityksiä: "Julkinen, sosiaalinen elämäni on ollut silkkaa peittelyyn ja valheeseen kietoutumista, siksi annan nyt 'totuuden' pubua." (1, SKS 251) Muiston kirjoittaminen auttaa myös prosessoimaan mennyttä, sillä muistelmatekstien kirjoittajat pyrkivät usein kohti mielekästä elämäntarinaa, jolla on selkeä päämäärä ja suunta ja satunnaisista tapahtumista rakentuu yhtenäinen juoni (17). Osassa tekstejä toisaalta oli käytetty taiteellista vapautta väljästi laaditun keruukutsun mahdollistamana: muistoja on kirjoitettu runojen ja aforismien muodossa ja teksteihin oli liitetty valokuvia ja piirroksia. Näin keruuseen osallistuminen on mahdollistanut taiteen terapeuttisen voiman hyödyntämisen kirjoittajan saadessa reflektoida muistojaan esimerkiksi runomuodossa (36). Runo on usein tiivistettyä ilmaisua, jossa sanat ovat mielen ja ruumiin eri kerroksissa resonoivia kuvia. Samalla sen metaforinen ilmaisu luo turvaa. Näin runon kirjoittaminen edesauttaa kokonaisvaltaista eheytymistä. (37)

\section{JOHTOPÄÄTÖKSET}

Mielisairaalamuistoaineiston potilaiden muistoissa häpeän kokemuksiin liittyy stigmatisoitumista ja häpeän voimistumista elämänkaaren varrella mielisairaalajaksojen myötä. Erityisen syviä ja sisäistettyjä häpeän tunteet ovat niillä muistelijoilla, jotka jo lapsena ovat altistuneet lähipiirin mielenterveysongelmille. Häpeä näyttäytyy niin Jähin (9) tutkimissa lapsuutta muistelevissa haastatteluissa kuin oman aineistoni mielenterveysongelmien monisukupolvisuutta käsittelevissä teksteissä ikään kuin sisäänrakennettuna ominaisuutena, josta on vaikea pyristellä irti. Yhden perheenjäsenen psyykkinen sairastuminen koskettaa koko perhettä ja aikaansaa häpeän tunteita, jotka voivat olla myöhemmin myötävaikuttamassa omaan sairastumiseen. Toisaalta perheenjäsenillä voi olla on myös ensisijainen rooli häpeän käsittelyssä ja siitä vapautumisessa.

Sairaalassa koettu henkinen väkivalta ja identiteetin rikkominen on monien potilaskokemusten muistelijoiden kohdalla syventänyt sairastumiseen, diagnosointiin ja lapsuuden ihmissuhteisiin liittyvää häpeää ja tehnyt siitä toipumisen entistä haastavammaksi. Psykiatrisen hoidon potilaskokemuksiin liittyy vahva häpeä, kehollisten traumamuistojen sanallistamisen vaikeus ja käsittelemättä jääneiden kipeiden asioiden aiheuttama ongelmien kroonistuminen. 
Kontrolliin, lääkehoitoon ja diagnooseihin perustuva psykiatrinen hoitojärjestelmä luo itsessään häpeää, kun taas empaattinen kohtelu sairaalassa vähentää sitä. Moni kirjoittaja korosti eroja eri sairaaloissa viettämiensä jaksojen välillä. Se korostaa toisaalta, miten suuri merkitys kunkin osaston hoitokulttuurilla on toipumisessa ja toisaalta, miten eri elämäntilanteessa sairaalassa olo saa erilaisia merkityksiä. Potilaiden teksteissä kuvataan negatiivisia kokemuksia yhtä lailla lähelle nykyaikaa kuin vanhempaankin ajankohtaan sijoittuvissa muistoissa. Potilaiden ajatuksia ja kokemuksia psykiatrisesta hoidosta olisi syytä kerätä ja tutkia laajemminkin hoidon kehittämisen tueksi.

Mielenterveysongelmien häpeäleimaa on viime vuosikymmeninä pyritty murtamaan ja asenneilmastoa muuttamaan sallivammaksi. Sairastumiseen ja hoidossa oloon liittyvä häpeä on silti edelleen toipumista ja hoitoon hakeutumista vaikeuttava ongelma. Tämän osoittaa myös mielisairaalamuistoaineisto. Analyysini perusteella näyttää siltä, että huonot kokemukset hoidosta, raskas lääkitys ja läheisten leimaava ja syrjivä suhtautuminen ovat lisänneet potilaiden häpeän tunteita ja vaikeuttaneet oman sairauden prosessointia ja siitä toipumista. Siksi pidänkin hoidon laadun parantamista, pakkotoimien vähentämistä, potilaan mielipiteen kuulemista, elämäntilanteen huomioimista ja hänen läheistensä tukemista toimivampina menetelminä häpeän lievittämisessä kuin häpeän purkuun tähtääviä kampanjoita, jotka hyvästä tarkoitusperästään huolimatta tulevat usein korostaneeksi mielenterveyskuntoutujien toiseutta.

Muistokeräykseen saatiin monenlaisia ja sairaaloita eri näkökulmista tarkastelevia kirjoituksia, mutta aineisto on kuitenkin väistämättä valikoitunutta. Sairaalakokemukset ovat usein hyvin kehollisia ja niihin liittyvien muistojen sanallistaminen on haasteellista. Traumaattista ja häpeän sävyttämää kokemusta, kuten pakkohoitoon joutumista tai psykoosia voi olla vaikeaa sovittaa elämän jatkumoon ja muodostaa siitä ehjää narratiivia $(36,38,39)$. On mahdollista, että suurinta häpeää mielisairaalaan joutumisestaan kokevat potilaat eivät ole halunneet osallistua muistokeruuseen. Osa sairaalakokemuksista on ehkä unohtunut tai halutaan unohtaa.
Muistokeruu on rajoituksistaan huolimatta ollut osaltaan hälventämässä häpeäleimaa. Keruukutsun julkistaminen on välittänyt viestin, että mielisairaalaan liittyvistä kokemuksista saa kertoa kuten mistä tahansa muistakin elämänvaiheista. Se on myös tarjonnut niin potilaille, omaisille kuin hoitohenkilökunnallekin keinon käsitellä häpeän tunteita ja pohtia niiden alkuperää. Hoitohenkilökunnan omat häpeän kokemukset sekä heidän käsityksensä erilaisten hoitokulttuurien vaikutuksesta potilaiden ja omaisten häpeän tunteisiin olisivat tärkeä jatkotutkimuksen aihe. Muistitiedon tutkijat (24) ovat korostaneet muistitiedon roolia akateemisen historiantutkimuksen piiloon jättämien seikkojen esiin nostajana. Myös kulttuurisella mielenterveystutkimuksella on avaimia vaikuttaa stigman purkamiseen. Syrjivien ja leimaavien kulttuuristen käsitysten ja käytänteiden taustan ja niiden rakentumisen tuominen näkyviin mahdollistaa käsitysten työstämisen, purkamisen ja parhaassa tapauksessa muuttamisen. (15)

Toivo toimii häpeän vastavoimana (2) ja näin ollen toivoa ylläpitävä hoitosuhde tai terapia voivat helpottaa häpeän tunteita. Myös kriisiin joutuneen läheiset voivat luoda toivoa. Näin omia vaikutusmahdollisuuksiaan kuvaa mielenterveyspotilaan omainen, joka myöhemmin opiskeli itse mielenterveyshoitajaksi:

"En tiedä olisinko onnellisempi, jos en olisi noita häpeän leimoja saanut, tai itse antanut iskeä, iholleni. Onhan sanottu: 'Mikä ei tapa, se vahvistaa'. Todennäköisesti minusta on tullut rohkeampi ja monessa mielessä kestävämpi. (...) Keskustellessani samansuuntaisissa elämäntilanteissa eläneiden ihmisten kanssa, voin olla tietämättäni terapeuttina ja saatan olla ainoa, jolle keskustelukumppani on kertonut sukunsa "häpeällisestä" mielisairaudesta." (1, SKS 427)

\section{RAHOITTAJAT:}

Koneen säätiö. 
Shame is the inexorable companion of mental illness. Hospitalisation is a particularly shameful experience for many and difficult to talk about. This article explores these feelings of shame and stigma in the light of memories of psychiatric hospitals written by patients and their relatives. I reflect on the way shame is depicted in patients' and their relatives' memories, what kind of situations have triggered it, and how its ultimate expression is conditioned.

The article is based on the Finnish Literary Society's (SKS) Muistoja ja kokemuksia mielisairaaloista [Mental hospital memories] material. It consist of 48 memories, which comprises events from the 1930s until 2010s. I used closed reading as a research method.

The feelings of shame are primarily constituted by a social stigma that is an intrinsic part of the individual's identity. They are associated with

\section{LÄHTEET}

(1) Suomalaisen Kirjallisuuden Seuran kansanrunousarkisto. Muistoja ja kokemuksia mielisairaalasta -muistokeruuaineisto. Koottu 2014-2015 yhteistyössä Kulttuurisen mielenterveystutkimusverkoston kanssa.

(2) Parpola A. Toivo/Häpeä. Psykiatria modernissa Suomessa. Keuruu: Otavan kirjapaino Oy; 2013, 282.

(3) Joutsenniemi, K. Lähiomaiset ja häpeäleima. Kirjassa: Korkeila J, Joutsenniemi K, Oksanen J, Sailas E. (toim.) Irti häpeäleimasta. Porvoo: Bookwell Oy; 2011, 43-51.

(4) Vuorela M, Aalto I. Häpeäleima tekee elämästä raskaan. Kirjassa: Korkeila J, Joutsenniemi K, Oksanen J, Sailas E. (toim.) Irti häpeäleimasta. Porvoo: Bookwell Oy; 2011, 32-37.

(5) Kielitoimiston sanakirja. Kotimaisten kielten keskus ja Kielikone Oy. Luettu 20.9.2018. http://www.kielitoimistonsanakirja.fi

(6) Korkeila J, Joutsenniemi K, Oksanen J, Sailas E. (toim.), Irti häpeäleimasta. Porvoo: Bookwell Oy; 2011.

(7) Korkeila J, Koski K. Kummat kokemukset, häpeäleima ja psykoosit. Kirjassa: Honkasalo M-L, Koski K. (toim.) Mielen rajoilla. Arjen kummat kokemukset. Turenki: Hansaprint Oy; 2017, 235-267.

(8) Kulmala, A. Kerrottuja kokemuksia leimatusta identiteetistä ja toiseudesta. Tampere: Tampere University Press; 2006. Luettu 13.5.2018. http://urn.fi/urn:isbn:951-44-6615-2 the mental health system's power structure and its coercive measures, such as isolation or involuntary psychiatric medication. Traumatic experiences are often described in the material through metaphorical language, which is imbued with a sense of transgenerational burden transfer. Even though attitudes towards mental health problems have changed, shame is still present, decreasing the chance of recovery. However, hope can be seen as an antidote to be administered by those close to the patient in their central role as family or carers.

Keywords: Mental hospitals, shame, mental health problems, psychiatric nursing.

Saapunut 08.10.2018

Hyväksytty 17.3.2019
(9) Jähi, R. Työstää, tarinoida, selviytyä. Vanhemman psyykkinen sairaus lapsuudenkokemuksena. Akateeminen väitöskirja: Tampereen Yliopisto; 2004, 62, 126.

(10) Syväri, S. Kamppailu stigmaa ja syrjäytymistä vastaan - kaksi potilastarinaa. Kirjassa: Helén, I. (toim.) Reformin pirstaleet. Mielenterveyspolitiikka hyvinvointivaltion jälkeen. Jyväskylä: Bookwell Oy; 2011, 231-258

(11) Kinnunen, A. Kohtaamisia kerronnan tilassa. Mielisairaalapotilaita koskevan muistelukerronnan rakentuminen. Elore 2013:20:2, 33-53. Luettu 1.9.2018. http://www.elore.fi/arkisto/2_13/kinnunen.pdf DOI: 10.30666/elore.79086

(12) Kinnunen A, Hänninen K. Saatteeksi: Hulluus kulttuurisena ilmiönä ja tutkimuskohteena. Elore 2016,23(1) Luettu 12.5.2018. http:// www.elore.fi/elore-12016-vol-23-hulluus/ saatteeksi-hulluus-kulttuurisena-ilmiona-jatutkimuskohteena/ DOI: 10.30666/elore.79239

(13) Tuohela, K. Sielun ja mielen sairaus. Varhaiset psyykkisen sairastamisen omaelämäkerrat Suomessa. Kirjassa: Ahlbeck J, Lappalainen P, Launis K, Tuohela K, Westerlund J. (toim.) Kipupisteissä. Sairaus, kulttuuri ja modernisoituva Suomi. Turku: Utukirjat; 2015, 195-232.

(14) Goffman, E. Stigma: Notes of the Management of Spoiled Identity. New Jersey: Simon and Schuster; 1963, 11-13 
(15) Jäntti S, Heimonen K, Kuuva S, Mäkilä A-S. (toim.) Hulluus ja kulttuurinen mielenterveystutkimus. Jyväskylä: Nykykulttuurin tutkimuskeskuksen julkaisuja 125, Jyväskylän yliopisto; 2019.

(16) Honkasalo M-L, Salmi H. (toim.) Terveyttä kulttuurin ehdoilla. Näkökulmia kulttuuriseen terveystutkimukseen. Turku: Turun yliopisto; 2012.

(17) Pöysä, J. Lähiluvun tieto. Näkökulmia kirjoitetun muistelukerronnan tutkimukseen. Helsinki: Suomen Kansantietouden tutkijain Seura; 2015, 14, 18-24, 25.

(18) Maanmieli, K. Suomalaiset käenpesät: väkivallan metaforat ja traumakokemuksen kuvaus mielisairaalamuistoissa. Psykoterapia; 2018a, 37(1), 37-48.

(19) Rechardt E, Ikonen P. Häpeä psyykkisen lamaannuksen aiheuttajana. - Duodecim 1994;110(3):278-286.

DOI: duo: 40053 (94030278)

(20) Janoff-Bulman, R. Characterological versus behavioral self-blame. Inquiries into depression and rape. J Pers Soc Psychol 1979:37: 17981809.

DOI:10.1037//0022-3514.37.10.1798.

(21) Greenberg L S, Paivio, S C. Working with the emotions in psychotherapy. New York: Guilford Press; 1997, 243-244, 253-254, 243-244, 253-254.

(22) Tainio, E. "Tulin kuntoutumaan, en olemaan...": nuori mielenterveyskuntoutuja tehostetussa palveluasumisessa - kokemuksia marginaalisuudesta ja köyhyydestä. Lisensiaatin tutkimus: Jyväskylän yliopisto; 2015.

(23) Kallinen K, Pirskainen H, Rautio S. Sensitiivinen tutkimuksessa. Menetelmät, kohderyhmät, haasteet ja mahdollisuudet. Tallinna: United Press Global; 2015.

(24) Fingerroos O, Haanpää R.

Muistitietotutkimuksen ydinkysymyksiä.

Kirjassa: Fingerroos O, Haanpää R, Heimo A, Peltonen U-M. (toim.) Muistitietotutkimus. Metodologisia kysymyksiä. Helsinki: Suomalaisen kirjallisuuden seura; 2006, 25-48.

(25) Korkiakangas, P. Muistoista rakentuva lapsuus. Agraarinen perintö lapsuuden työnteon ja leikkien muistelussa. Helsinki: Suomen Muinaismuistoyhdistys; 1996.

(26) Kivimäki, V. Murtuneet mielet. Taistelu suomalaissotilaiden hermoista 1989-1945. Helsinki: WSOY; 2013, 365-394.

(27) Siltala, P. Taakkasiirtymä. Trauman siirto yli sukupolvien. Tampere: Hermes Oy; 2016, 5.
(28) Muistoihin kaivertuneet tilat -tutkijaryhmälle v. 2017 lähetetty arkistoimaton potilaan/ omaisen muisto.

(29) Lebowitz M S, Ahn W K. Effects of biological explanations for mental disorders on clinicians' empathy. Proc. Natl. Acad. Sci 2014:111(50): 17786-17790. DOI: $10.1073 /$ pnas.1414058111

(30) Kaufman, G. The psychology of shame. Theory and treatment of shamebased syndromes. New York: Springer; 1989, 20.

(31) Malinen, B. The nature, origins, and consequences of Finnish shame-proneness. A grounded theory study. Akateeminen väitöskirja: Helsingin Yliopisto; 2010, 150.

(32) Aromaa E, Toivanen A, Tuulari J, Wahlbeck K. Personal stigma and use of mental health services among people with depression in a general population in Finland. BMC Psychiatry; 2011, 11-52.

DOI: 10.1186/1471-244X-11-52

(33) Anttonen, S. Hyvää elämää leimasta huolimatta. Kirjassa: Korkeila J, Joutsenniemi K, Oksanen J, Sailas E. (toim.) Irti häpeäleimasta. Porvoo: Bookwell Oy; 2011,108-118.

(34) Huttunen M, Raaska K. Psyykenlääkkeiden käytön sudenkuopat. Duodecim 2015, 131(18) 1651-1657. DOI: duo12449 (012.449).

(35) Huttunen, M. Hoitosuhteiden ja lääkehoidon psykoterapeuttisesta merkityksestä. Kirjassa: Huttunen M, Kalska H. (toim.) Psykoterapiat. Porvoo: Bookwell Oy; 2014, 337.

(36) Maanmieli, K. Luovat terapiat ja empaattisen kohtaamisen kaipuu suomalaisten mielisairaalamuistojen valossa. Kirjallisuusterapia; 2018b, 26(1-2), 4-9.

(37) Mertanen, H. Poeettinen ja metaforinen kieli hoitotyössä. Kirjassa: Ihanus, J. (toim.) Sanat että hoitaisimme. Terapeuttinen kirjoittaminen. Helsinki: Duodecim; 2009, 233-254

(38) Holma, J. Psykoosi narratiivina. Kirjassa: Haarakangas J, Seikkula J. (toim.) Psykoosi - uuteen hoitokäytäntöön. Tampere: Kirjayhtymä; 1999, 206-219.

(39) Suokas-Cunliffe, A. Trauma - omaan elämäntarinaan yhdistymätön mielen loinen. Lääketiede 2006; 21(5): 19-23.

KAROLINA MAANMIELI
FT, apurahatutkija
Jyväskylän yliopisto
Musiikin, taiteen ja kulttuurintutkimuksen laitos

